\title{
ZAKAT SEBAGAI IBADAH MALIYAH IJTIMA'IYAH DALAM PERSPEKTIF ILMU EKONOMI ISLAM
}

\author{
Widi Nopiardo \\ Program Studi Perbankan Syariah STAIN Batusangkar \\ Jl. Jenderal Sudirman No. 137, Lima Kaum Batusangkar \\ e-mail: widinopiardo@rocketmail.com
}

\begin{abstract}
Zakat is a part of the discussion of Islamic economics. In the perspective of Islamic economics rakeat has a very important role. Zakat has a strategic role in the fight against poverty or economic development. Zakat has an enormous influence in many respects human life, among which is the effect on the economy. Zakat is a tool that can be used to stabilize the economic life, rakat can strengthen economic solidarity among members of society, and ultimately will create economic stability. In addition to containing the values of worship, rakat also contains socio-economic value to people's lives.
\end{abstract}

Kata kunci: zakat, perspektif, dan ilmu ekonomi Islam

\section{PENDAHULUAN}

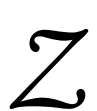
akat adalah salah satu kewajiban dalam Islam, ia termasuk salah satu dari rukun Islam. Alquran dan sunnah serta ijma' telah menunjukkan kewajibannya, barang siapa mengingkari kewajibannya maka ia termasuk orang-orang zalim yang berhak mendapatkan sanksi dari Allah SWT.

Dalam Islam kewajiban zakat memiliki makna yang sangat fundamental. Selain berkaitan erat dengan aspek ketuhanan, zakat juga erat kaitannya dengan aspek sosial, ekonomi, dan kemasyarakatan. Zakat memiliki peran sebagai distribusi dan redistribusi penghasilan dari golongan mampu kepada golongan yang kurang atau tidak mampu dan pada dasarnya merupakan pengembalian sebagian harta kekayaan orang-orang yang mampu untuk menjadi milik orang yang tidak berpunya (Ahmad, 1979: 88).

Ada kaitan antara ilmu ekonomi Islam dengan zakat. Bahwa ilmu ekonomi Islam merupakan bidang ilmu yang mengkaji tentang perilaku ekonomi umat Islam yang mendasarkan diri pada nilai-nilai Islam. Sedangkan zakat, merupakan bagian dari pembahasan ilmu ekonomi Islam yang masuk dalam sistem keuangan Islam.

Berangkat dari hubungan tersebut maka pada tulisan ini akan dibahas tentang zakat sebagai ibadah maliyah ijtima'iyah dalam perspektif ilmu ekonomi Islam agar tergambar bagaimana zakat berkontribusi positif bagi perekonomian. Sebagaimana diketahui pengembangan infrastruktur zakat erat kaitannya 
dengan perkembangan disiplin ilmu ekonomi Islam. Oleh karena itu, pada tulisan ini akan dibahas konsep zakat, konsep ilmu ekonomi Islam, dan zakat sebagai ibadah maliyah ijtima'iyah dalam perspektif ilmu ekonomi Islam.

\section{KONSEP ZAKAT}

\section{Definisi Zakat}

Secara etimologis, zakat berasal dari kata dasar bahasa Arab zaka yang berarti berkah, tumbuh, bersih, baik, dan bertambah. Sedangkan secara terminologis di dalam fikih, zakat adalah sebutan atau nama bagi sejumlah harta tertentu yang diwajibkan Allah SWT supaya diserahkan kepada orang-orang yang berhak (mustahiq) oleh orangorang yang wajib mengeluarkan zakat (muzakki) (Ambary, dkk., 1999: 224).

Ada pendapat beberapa ulama mengenai pengertian zakat, yaitu (Wahbah Al Zuhayly, 1995: 83-84):

1. Menurut mazhab Maliki, definisi zakat adalah "mengeluarkan sebagian yang khusus dari harta yang khusus pula yang telah mencapai nisab (batas kuantitas yang mewajibkan zakat) kepada orang-orang yang berhak menerimanya (mustahiq)nya.

Dengan catatan, kepemilikan itu penuh dan mencapai haul (setahun), bukan barang tambang dan bukan pertanian."

2. Menurut mazhab Hanafi, zakat adalah "menjadikan sebagian harta yang khusus dari harta yang khusus sebagai milik orang yang khusus, yang ditentukan oleh syari' at karena Allah SWT."

3. Menurut mazhab Syafi'i, zakat adalah sebuah ungkapan untuk keluarnya harta atau tubuh sesuai dengan cara khusus.

4. Menurut mazhab Hambali, zakat adalah hak yang wajib (dikeluarkan) dari harta yang khusus untuk kelompok yang khusus pula.

Menurut istilah ekonomi, zakat merupakan tindakan pemindahan kekayaan dari golongan kaya kepada golongan tidak punya (Adiwarman Karim, 2001: 32). Salah satu ajaran penting yang terdapat dalam agama Islam adalah urgensi zakat kaitannya dengan pengentasan kemiskinan. Sebagai sebuah dinamika keagamaan, zakat merupakan bentuk kesaksian manusia (syahadah al-insan) pada rukun Islam yang keempat di hadapan Allah yang muaranya tertuju pada dimensi kemanusiaan.

\section{Landasan Kewajiban Zakat}

Zakat telah difardhukan di Madinah pada bulan Syawal tahun kedua hijrah setelah kepada umat Islam diwajibkan berpuasa Ramadhan.

Zakat merupakan salah satu rukun Islam yang selalu disejajarkan dengan shalat. Inilah yang menunjukkan betapa pentingnya zakat sebagai salah satu rukun Islam (Abdul Hamid Mahmud, 2006: 1). Dasar-dasar atau landasan kewajiban mengeluarkan zakat disebutkan dalam:

\section{Landasan dalam Alquran}


1. Surat al-Baqarah: 43

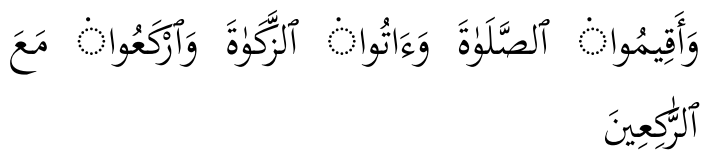

Dan Dirikanlah shalat, tunaikanlah zakat dan ruku'lah beserta orangorang yang ruku' (Q.S. al-Baqarah [2]: 43).

2. Surat at-Taubah: 103

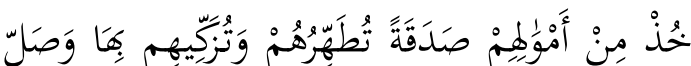

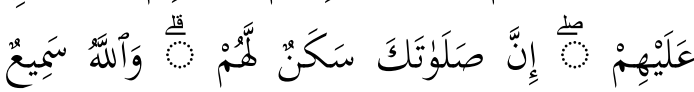
عَلِيَمْ

Ambillah zakat dari sebagian harta mereka, dengan zakat itu kamu membersihkan dan mensucikan mereka dan mendoalah untuk mereka. Sesungguhnya doa kamu itu (menjadi) ketenteraman jiwa bagi mereka. dan Allah Maha mendengar lagi Maha Mengetahui (Q.S. atTaubah [9]: 103).

3. Surat al-An'am: 141

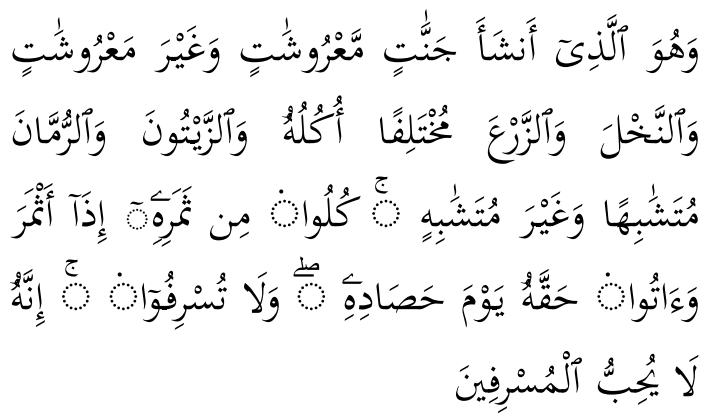

Dan Dialah yang menjadikan kebunkebun yang berjunjung dan yang tidak berjunjung, pohon korma, tanam-tanaman yang bermacammacam buahnya, zaitun dan delima yang serupa (bentuk dan warnanya) dan tidak sama (rasanya). Makanlah dari buahnya (yang bermacammacam itu) bila dia berbuah, dan tunaikanlah haknya di hari memetik hasilnya (dengan disedekahkan kepada fakir miskin); dan janganlah kamu berlebih-lebihan. Sesungguhnya Allah tidak menyukai orang yang berlebih-lebihan (Q.S. alAn'am [6]: 141).

\section{Surat at-Taubah: 5}

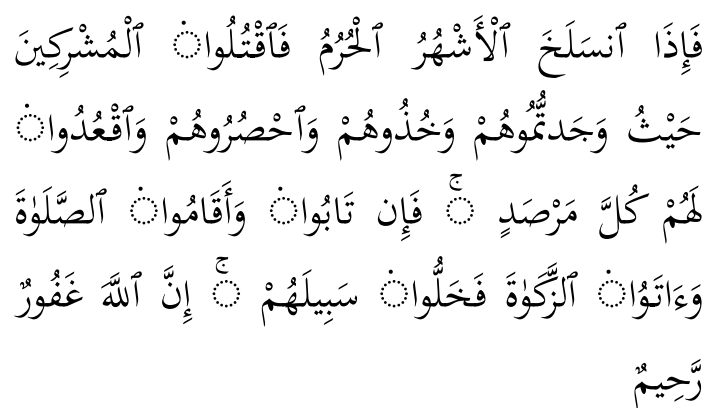

Apabila sudah habis bulan-bulan haram itu maka bunuhlah orangorang musyrikin itu di mana saja kamu jumpai mereka, dan tangkaplah mereka. Kepunglah mereka dan intailah di tempat pengintaian. Jika mereka bertaubat dan mendirikan shalat dan menunaikan zakat, maka berilah kebebasan kepada mereka untuk berjalan. Sesungguhnya Allah Maha Pengampun lagi Maha Penyayang (Q.S. at-Taubah [9]: 5) (Al-Fauzan, 2006: 244).

\section{Landasan dalam Sunnah}

1. Hadis yang diriwayatkan oleh Bukhari dan Muslim dari Abdullah bin Umar Rasulullah bersabda:

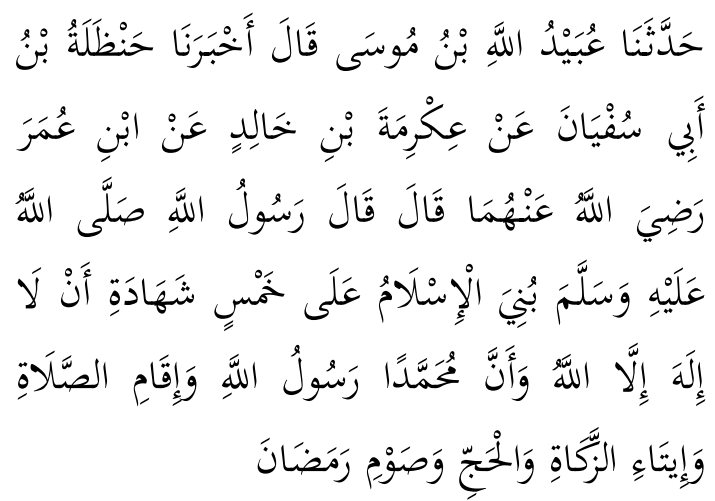


Telah menceritakan kepada kami [Abdullah bin Musa] dia berkata, telah mengabarkan kepada kami [Hanzhalah bin Abu Sufyan] dari ['Ikrimah bin Khalid] dari [Ibnu Umar] berkata: Rasulullah shallallahu 'alaihi wasallam bersabda: "Islam dibangun di atas lima (landasan); persaksian tidak ada Ilah selain Allah dan sesungguhnya Muhammad utusan Allah, mendirikan shalat, menunaikan zakat, haji dan puasa Ramadhan (H.R. Bukhari Nomor 7)

2. Hadis yang diriwayatkan oleh Ahmad dan Muslim dari Syaiban bin Farrukh

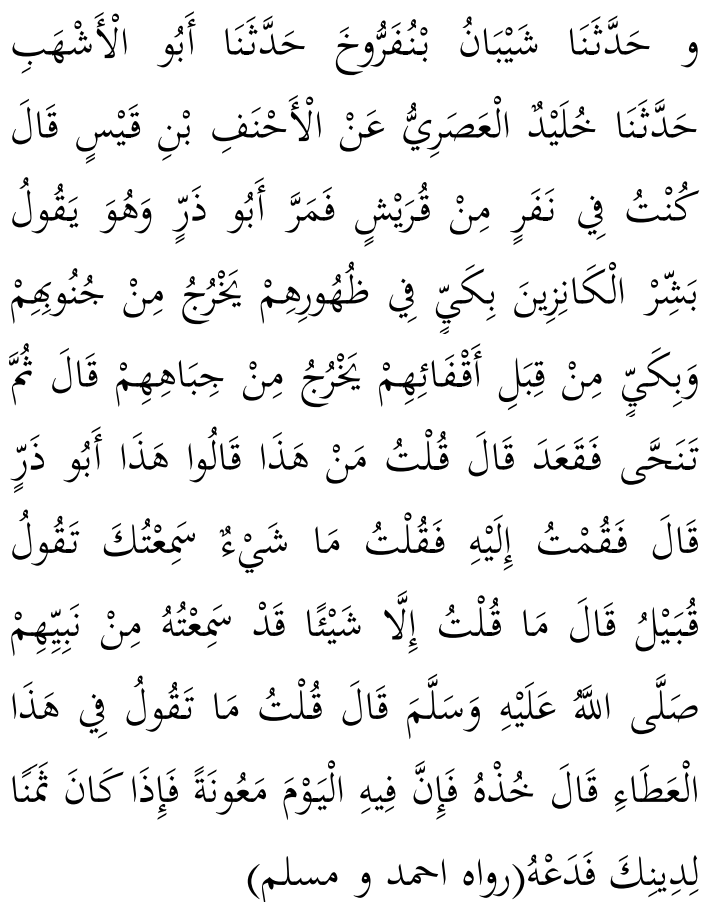

Dan Telah menceritakan kepada kami [Syaiban bin Farrukh] telah menceritakan kepada kami [Abul Asyhab] telah menceritakan kepada kami [Khulaid Al 'Ashari] dari [Al Ahnaf bin Qais] ia berkata; Saya pernah berada dalam sebuah rombongan orang-orang Quraisy, lalu [Abu Dzar] lewat sambil mengatakan, "Berilah kabar gembira kepada orang-orang yang menumpuk harta (dan tidak membayar zakatnya), bahwa mereka akan disiksa dengan seterika di punggung mereka yang keluar dari lambung dari tengkuk mereka." Setelah itu, ia menyingkir dan duduk. Kemudian saya bertanya, "Siapa ini?" orang-orang pun menjawab, "Ini adalah Abu Dzar." Maka aku pun mendekatinya dan bertanya, "Apa ucapanmu yang baru saja aku dengar tadi?" Abu Dzar menjawab, "Tidaklah aku mengatakan sesuatu tadi, kecuali aku telah mendengarnya dari Nabi shallallahu 'alaihi wasallam." Kemudian aku tanyakan, "Bagaimana pendapatmu tentang pemberian ini?" Abu Dzar menjawab, "Ambillah karena pemberian itu sekarang sebagai pertolongan, namun jika pemberian itu untuk membayar agamamu, maka tinggalkanlah. (H.R. Ahmad Nomor 20511 dan Muslim Nomor 1657)

3. Hadis yang diriwayatkan oleh Thabrani dalam buku Al Ausath dan As Saghir dari Ali

$$
\begin{aligned}
& \text { ان الله فرض على اغنياء المسا عين في اموا لمم } \\
& \text { بقد ر الذي يسع فقرا ئهم ولن يجها الفقراء اذا } \\
& \text { جا عوا او عروا الا بما يصنع اغنيا ئهم الا وان الله } \\
& \text { يحا سبهم حسابا شديدا و يعذ بهم عذاباليما }
\end{aligned}
$$

Allah Ta'ala mewajibkan zakat pada harta orang-orang kaya dari kaum muslimin sejumlah yang dapat melapangi orang-orang miskin di antara mereka. Fakir miskin itu tiadalah akan menderita menghadapi kelaparan dan kesulitan sandang kecuali karena perbuatan golongan kaya, ingatlah Allah akan mengadili 
mereka nanti secara tegas dan menyiksa mereka dengan pedih (H.R. Thabrani) (Sabiq, 1982: 193).

\section{Rukun Zakat}

Rukun zakat adalah mengeluarkan sebagian dari nisab (harta) yang dengan melepaskan kepemilikan terhadapnya, menjadikannya sebagai milik orang fakir dan menyerahkan kepadanya atau harta tersebut diserahkan kepada wakilnya yakni imam atau orang yang bertugas untuk memungut zakat. (Syaikh Muhammad Abdul Malik Ar Rahman, 2003: 97)

\section{Syarat Wajib Zakat}

Wahbah Al-Zuhayly (dalam Fakhruddin, 2008: 32) membagi syarat wajib zakat menjadi:

1. Merdeka, artinya bukan budak.

2. Beragama Islam.

3. Baligh dan berakal.

4. Harta yang dikeluarkan adalah harta yang wajib dizakati.

5. Harta yang dimiliki sudah mencapai nisab (batas minimal banyaknya harta yang dimiliki) atau senilai dengannya.

6. Memiliki harta secara sempurna, harta yang dimiliki adalah miliknya sendiri.

7. Kepemilikan harta telah mencapai setahun, menurut hitungan tahun qamariyah.

8. Harta tersebut bukan merupakan harta hasil hutang.

9. Melebihi kebutuhan dasar atau pokok.

10. Harta tersebut harus didapatkan dengan cara yang baik dan halal.

11. Berkembang.

\section{Syarat-syarat Sah Pelaksanaan Zakat}

Di antara syarat-syarat sah pelaksanaan zakat terdiri atas (Wahbah Al-Zuhayli, 1995: 114-118):

1. Niat

2. Tamlik

kepemilikan

(memindahkan penerimanya)

kepada

\section{Harta (Maal) yang Wajib Dikeluarkan Zakatnya}

Di dalam kitab-kitab hukum (fikih) Islam harta kekayaan yang wajib dizakati digolongkan ke dalam kategori (Ridwan Mas'ud dan Muhammad, 2005: 45):

1. Emas, perak, dan uang (simpanan) (Q.S. at-Taubah [9]: 34-35)

2. Barang yang diperdagangkan (Q.S. al-Baqarah [2]: 267)

3. Hasil peternakan (Q.S. al-Baqarah [2]: 267)

4. Hasil bumi (Q.S. al-Baqarah [2]: 267)

5. Hasil tambang dan barang temuan (Q.S. al-Baqarah [2]: 267)

\section{Hikmah Zakat}

Di antara hikmah zakat, yaitu:

1. Menolong orang yang lemah dan susah agar dia dapat menunaikan kewajibannya terhadap Allah dan terhadap makhluk Allah (masyarakat).

2. Membersihkan diri dari sifat kikir dan akhlak yang tercela, serta membayarkan amanat kepada orang yang berhak dan berkepentingan.

3. Sebagai ucapan syukur dan terima kasih atas nikmat 
kekayaan yang diberikan kepadanya.

4. Guna menjaga kejahatankejahatan yang akan timbul dari si miskin dan yang susah

5. Guna mendekatkan hubungan kasih sayang dan cinta mencintai antara si miskin dan si kaya (Ar Rahman, 2003: 17).

6. Penyucian diri bagi orang yang berpuasa dari kebatilan dan kekokohan untuk memberi makan kepada orang miskin serta sebagai rasa syukur kepada Allah atas selesainya menunaikan kewajiban puasa (Rasyid, 1994: 217-218)

\section{Macam-macam Zakat}

Zakat terbagi atas dua jenis yakni zakat fitrah dan zakat maal (zakat harta). Zakat fitrah merupakan zakat yang wajib dikeluarkan muslim menjelang Idul Fitri pada bulan Ramadhan. Besar zakat ini setara dengan 2,5 kilogram/3,5 liter makanan pokok yang ada di daerah bersangkutan. Sedangkan zakat maal (zakat harta), mencakup hasil perniagaan, pertanian, pertambangan, hasil laut, hasil ternak, harta temuan, emas dan perak. Masing-masing tipe memiliki perhitungannya sendiri-sendiri.

\section{KONSEP ILMU EKONOMI ISLAM}

\section{Definisi Ilmu Ekonomi Islam}

Sejumlah pakar ekonomi Islam telah mencoba memberikan definisi tentang ilmu ekonomi Islam, di antaranya:
1. Menurut Hasanuzzaman, (dalam Imamudin Yuliadi, 2006: 8) Islamic economics is the knowledge and application of injunctions and rules of the shari'ah that prevent injustice in the acquition and disposal of material resources in order to provide satisfaction to human beings and enable them to perform their obligations to Allah and the society. Maksudnya suatu pengetahuan dan aplikasi dari perintah dan peraturan dalam syariah yaitu untuk menghindari ketidakadilan dalam perolehan dan pembagian sumber daya material agar memberikan kepuasan manusia, sehingga memungkinkan manusia melaksanakan tanggung jawabnya terhadap Tuhan dan masyarakat.

2. Menurut M.A Mannan, Islamic economics is a social science which studies the economics problems of a people imbued with the values of Islam (Muhammad Abdul Mannan, 1980: 3) Maksudnya: "Ilmu ekonomi Islam adalah suatu ilmu pengetahuan sosial yang mempelajari permasalahan ekonomi dari orang-orang memiliki nilai-nilai Islam."

3. Menurut $M$. Umer Chapra (dalam Mustafa Edwin Nasution dkk., 2006: 16) Islamic economics was defined as that branch of knowledge which helps realize human well-being through an allocation and distribution of scarce resources that is in confinnity with Islamic teaching without unduly curbing Individual freedom or creating continued macroeconomic and ecological imbalances. Menurut 
Chapra ilmu ekonomi Islam adalah sebuah pengetahuan yang membantu upaya realisasi kebahagiaan manusia melalui alokasi dan distribusi sumber daya yang terbatas yang berada dalam koridor yang mengacu pada pengajaran Islam tanpa memberikan kebebasan individu atau tanpa perilaku makro ekonomi yang berkesinambungan dan tanpa ketidakseimbangan lingkungan

4. Menurut Syed Nawab Haider Naqvi, ilmu ekonomi Islam, singkatnya, merupakan kajian tentang perilaku ekonomi orang Islam representatif dalam masyarakat muslim modern. (Syed Nawab Haider Naqvi, 2009: 28)

\section{Perkembangan dan Eksistensi Ekonomi Islam}

Ilmu ekonomi Islam sangat urgen dan ilmu ini berkembang secara bertahap sebagai suatu bidang ilmu interdisiplin yang menjadi bahan kajian para fukaha, mufassir, filsuf, sosiolog, dan politikus. Sejumlah cendekiawan Muslim terkemuka telah memberikan kontribusi yang besar terhadap kelangsungan dan perkembangan peradaban dunia, khususnya pemikiran ekonomi, melalui sebuah proses evolusi yang terjadi selama berabad-abad.

Ekonomi Islam saat ini telah berkembang dengan pesat. Hal ini dapat dilihat dari maraknya lembaga-lembaga perekonomian baik bisnis maupun keuangan yang melaksanakan usahanya dengan berdasarkan syariat Islam. Beberapa lembaga tersebut antara lain bank syariah, asuransi syariah, hotel syariah, lembaga zakat, dan sebagainya.

Keberadaan lembaga zakat akan membantu perkembangan ekonomi Islam. Dari sisi mikro maupun makro zakat mempunyai pengaruh positif dalam perekonomian. Penggalakan sadar zakat dan pengelolaan zakat secara baik dan profesional akan mampu memecahkan

masalah perekonomian.

\section{ZAKAT SEBAGAI IBADAH MALIYAH IJTIMA'IYAH DALAM PERSPEKTIF ILMU EKONOMI ISLAM}

Berangkat dari definisi ilmu ekonomi Islam yang telah dipaparkan sebelumnya yaitu ilmu pengetahuan sosial yang mempelajari masalah-masalah ekonomi masyarakat yang diilhami oleh nilai-nilai Islam, berikut ini diutarakan tentang zakat sebagai ibadah maliyah ijtima'iyah (ibadah yang berkaitan dengan ekonomi keuangan kemasyarakatan) dalam perspektif ilmu ekonomi Islam.

\section{Zakat sebagai Landasan Sistem Perekonomian Islam}

Islam selain mendorong
ummatnya untuk mencari
penghasilan setinggi-tingginya
(pertumbuhan ekonomi), Islam juga
mendorong dan memberikan sistem
distribusi kekayaan yang adil
sebagaimana zakat, infak, dan
sedekah. Dalam hal ini Islam


mengobati kemiskinan langsung ke akar permasalahannya, yaitu mengobati keserakahan manusia. Islam memandang bahwa sesungguhnya yang perlu dientaskan terlebih dahulu adalah orang-orang kaya (muzakki), sebab dengan zakat, infaq, dan shodaqoh yang mereka salurkan, maka mereka mengentaskan kemiskinan yang terdapat di dalam diri mereka sendiri, seperti sifat tamak, serakah, dan kikir. Jadi Islam membersihkan mereka dari kemiskinan yang sifatnya ruhiyah, setelah itu dampaknya dapat menyebar ke obyek zakat, infak, dan sedekah.

Zakat adalah landasan sistem perekonomian Islam dan menjadi tulang punggungnya. Sistem ekonomi Islam berdasarkan pengakuan bahwa Allah adalah pemilik alam semesta ini, maka hanya Dia yang berhak mengatur masalah pemilikan, hak-hak dan penyaluran serta pendistribusian harta. Zakat adalah pencerminan dari semua itu, karena ia merupakan salah satu hak terpenting yang dijadikan Allah di dalam pemilikan.

Komponen pertumbuhan ekonomi juga bisa dilihat dari neraca berjalan. Defisit neraca berjalan diindikasikan arus keluar barang (ekspor) lebih kecil dibandingkan dengan arus masuk (impor). Padahal, kuatnya ekonomi suatu bangsa salah satunya dicirikan dengan surplusnya neraca berjalan.

Zakat mendorong surplusnya neraca berjalan pada suatu negara sehingga landasan perekonomian negara menjadi kokoh. Hal ini ditandai dengan muzakki secara konsisten menunaikan zakatnya, sehingga dengan zakat tersebut kemiskinan dapat dientaskan. Salah satu penyebab kemiskinan adalah kurangnya modal untuk berusaha (untuk bangkit dari kemiskinan). Sementara itu sistem zakat menjadikan modal selalu dalam perputaran. Dengan ini pula kita dapat memahami firman Allah:

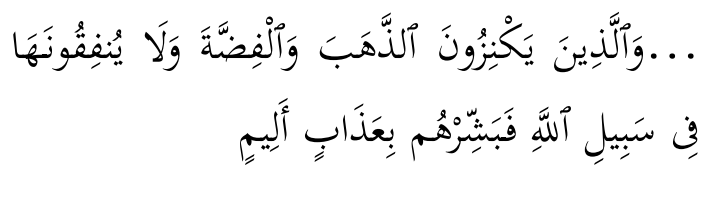

"...Dan orang-orang yang menyimpan emas dan perak dan tidak menafkahkannya pada jalan Allah, maka beritahukanlah kepada mereka (bahwa mereka akan mendapat) siksa yang pedih" (Q.S. At Taubah [9]:34).

Tingginya perputaran modal di suatu negara akan mengantarkan negara tersebut memiliki produktifitas yang tinggi pula dalam kegiatan ekonomi. Secara tidak langsung aktifitas ekonomi yang dilakukan dengan distribusi pendapatan yang adil maka akan mempengaruhi perekonomian kea rah yang lebih baik.

\section{Zakat sebagai Asas Sistem Fiskal}

Dalam perspektif ekonomi Islam, zakat dipandang sebagai suatu hal yang sangat penting. Bahkan zakat dapat dijadikan instrumen utama kebijakan fiskal suatu negara. Jika dikelola dengan baik zakat akan menjadi salah satu solusi dari sasaran akhir perekonomian suatu negara, yakni terciptanya kesejahteraan bagi masyarakat. 
Sebenarnya kebijakan fiskal telah sejak lama dikenal dalam teori ekonomi Islam, yaitu sejak zaman Rasulullah dan Khulafaur Rasyidin, dan kemudian dikembangkan oleh para ulama. Ibnu Khaldun (1404) mengajukan obat untuk resesi berupa mengecilkan pajak dan meningkatkan pengeluaran pemerintah, pemerintah adalah pasar terbesar, ibu dari semua pasar, dalam hal besarnya pendapatan dan penerimaannya. Jika pasar pemerintah mengalami penurunan, wajar bila pasar yang lain pun akan ikut menurun, bahkan dalam agregat (keseluruhan) yang lebih besar. Laffer, penasihat ekonomi Presiden Ronald Reagan, yang menemukan teori Laffer's Curve, berterus terang bahwa ia mengambil ide Ibnu Khaldun. Selain itu, Abu Yusuf (798) adalah ekonom pertama yang menulis secara khusus tentang kebijakan ekonomi dalam kitabnya, al-Kharaj, yang menjelaskan tanggung jawab ekonomi pemerintah untuk memenuhi kebutuhan rakyatnya. Abu Yusuf sangat menentang adanya pajak atas tanah pertanian dan menyarankan diganti dengan zakat pertanian yang dikaitkan dengan jumlah hasil panennya. Abu Yusuf membuat rincian bagaimana membiayai pembangunan jembatan, bendungan, dan irigasi (Karim, 2001: 25).

Penerimaan zakat dan kums dihitung secara proporsional, yaitu dalam persentase dan bukan ditentukan nilai nominalnya. Secara ekonomi makro, hal ini akan menciptakan built-in stability. la akan menstabilkan harga dan menekan inflasi (Karim, 2007: 135).

\section{Zakat sebagai Sarana untuk Meningkatkan Permintaan}

Pada dasarnya, zakat diambil dari yang kaya dan diberikan kepada yang miskin. Distribusi zakat kepada golongan fakir miskin sudah tentu akan dapat menambahkan kemampuan mereka untuk meningkatkan penggunaan (utility) mereka.

Selain itu zakat merupakan instrumen publik yang memiliki pengaruh terhadap sisi demand dalam perekonomian. Secara teori eksistensi zakat akan meningkatkan kurva permintaan melalui agregat demand yang meningkat akibat daya beli masyarakat (mustahik) yang didorong oleh distribusi zakat. Tentu saja hal ini secara jangka pendek akan meningkatkan harga. Namun peningkatan harga tersebut otomatis akan meningkatkan harga. Namun peningkatan harga tersebut otomatis akan meningkatkan revenue produsen (Total Revenue $=$ Price $\mathrm{X}$ Quantity). Dan jika informasi peningkatan harga ini diketahui semua pelaku pasar (symetrix information) maka tentu akan mengundang pelaku baru untuk masuk ke pasar. Dengan kata lain respon tersebut akan meningkatkan penawaran selanjutnya harga akan terkoreksi. Meskipun harga telah turun bukan berarti kuantitas produksi keseimbangan berkurang juga tetapi tetap meningkat, inilah kemudian menunjukkan bahwa zakat mendorong pertumbuhan ekonomi, begitu seterusnya seiring 
pertumbuhan ekonomi (Ali Sakti, 2007: 183-184 )

Pada dasarnya, golongan fakir miskin tidak mempunyai daya permintaan yang tinggi. Pendapatan mereka yang rendah menyebabkan mereka tidak bisa mencukupi keperluan hidup mereka. Maka kecenderungan daya beli di kalangan mereka adalah sangat rendah dibanding dengan kecenderungan daya beli di kalangan orang-orang kaya.

Dengan yang demikian, zakat yang diterima akan membuat mereka meningkatkan penggunaan mereka terutama bagi barang keperluan. Peningkatan kepada permintaan ini sudah tentu dapat mendorong pengeluaran yang lebih terutama bagi barang keperluan.

\section{Zakat sebagai Sarana untuk Pembangunan Negara}

Pembangunan

ekonomi merupakan bagian dari pembangunan negara. Hal tersebut mutlak harus dilakukan oleh suatu negara untuk mensejahterahkan kehidupan masyarakat. Pembangunan negara merupakan kewajiban bagi seluruh penduduk ne gara tersebut, bukan hanya dilakukan oleh pemerintah. Dalam proses pembangunan negara diperlu kan sinergisitas antara pemerintah, masyarakat, dan segenap pihak terkait.

Zakat sangat berperan penting
bagi pertumbuhan dan
pembangunan ekonomi negara.
Zakat menyebabkan meningkatnya
pendapatan fakir dan miskin yang
pada akhirnya konsumsi yang

dilakukan juga akan mengalami peningkatan. Secara teori, dengan adanya peningkatan konsumsi maka sektor produksi dan investasi akan mengalami peningkatan. Dengan demikian, permintaan terhadap tenaga kerja ikut meningkat sehingga pendapatan dan kekayaan masyarakat juga akan mengalami peningkatan. Fenomena tersebut mengindikasikan adanya pertumbuhan kehidupan ekonomi dan sosial masyarakat.

\section{Zakat sebagai Sarana Pengembangan Potensi Ekonomi Umat}

Posisi zakat sebagai modal untuk pemberdayaan ekonomi umat tampaknya masih mengandung sejumlah kendala yang cenderung mengarah kepada kondisi serba dilematis. Dalam konteks sekarang ini menyeruak isu pemberdayaan ekonomi umat sebagai salah satu potensi untuk melepaskan kaum lemah dari keterpurukan sosial ekonomi, namun isu tersebut ternyata masih berkutat dalam tataran wacana yang menampilkan masalah dan menjanjikan harapan belaka ketimbang sebuah realitas ideal (Khasanah, 2010: 227).

Agar pelaksanaannya dapat efektif, Yusuf Qardhawi menyatakan bahwa urusan zakat sebaiknya jangan dikerjakan sendiri oleh muzakki (orang yang mengeluarkan zakat), melainkan dipungut oleh petugas zakat yang telah ditunjuk oleh negara (dalam konteks Indonesia adalah Badan Amil Zakat Nasional atau Lembaga Amil Zakat). 
Pada akhirnya apabila zakat benar-benar dapat berjalan efektif, diharapkan tercapai sosial safety nets (kepastian terpenuhinya hak minimal kaum papa) serta berputarnya roda perekonomian umat, mendorong pemanfatan dana 'diam' (idle), mendorong inovasi dan penggunaan IPTEK serta harmonisasi hubungan si kaya dan si miskin. Sehingga pada akhirnya kehidupan umat yang ideal dengan sendirinya akan terwujud.

\section{Zakat sebagai Alternatif Penanggul angan Kemiskinan}

Kemiskinan yang terjadi di Indonesia pada dasarnya disebabkan rendahnya pendidikan, lemahnya skill (keahlian), dan kurangnya modal. Penangggulangan kemiskinan dan kesenjangan sosial merupakan salah satu agenda utama dalam pembangunan bangsa. Berbagai program telah dilakukan seperti BLT, proyek padat karya, bantuan beras untuk keluarga miskin, BOS, dan lain-lain, namun program-program tersebut belum secara maksimal dapat menanggulangi kemiskinan di Indonesia (M. Arifin Purwakanta dan Noor Aflah, 2011: 41).

Zakat memiliki peranan yang sangat strategis dalam upaya pengentasan kemiskinan. Tujuan zakat tidak sekedar menyantuni orang miskin secara konsumtif, tetapi mempunyai tujuan yang lebih permanen yaitu mengentaskan kemiskinan. Salah satu yang menunjang kesejahteraan hidup di dunia dan menunjang hidup di akhirat adalah adanya kesejahteraan sosial-ekonomi. Ini merupakan seperangkat alternatif untuk mensejahterakan umat Islam dari kemiskinan dan kemelaratan. Untuk itu perlu dibentuk lembaga-lembaga sosial Islam sebagai upaya untuk menanggulangi masalah sosial tersebut.

Sudah menjadi rahasia umum bahwa kemiskinan merupakan masalah dalam ekonomi. Salah satu instrumen dalam ekonomi Islam adalah zakat, dimana jika zakat dikelola dengan baik maka dapat mengoptimalkan untuk membantu sasaran zakat.

Idealnya, zakat yang diberikan harus bisa menyelesaikan problem kemiskinan dengan cara memberi peluang, pelatihan, pendidikan, motivasi dan modal untuk usaha. Dari bekal-bekal itulah para mustahik diharapkan bisa berubah nasibnya dan terdongkrak ekonominya. Pendistribusian zakat yang telah dterima ditujukan untuk membantu beragam masalah umat. Dana yang dikumpulkan dapat dimanfaatkan untuk meningkatkan kesejahteraan lahir batin masyarakat (Mamluatul Maghfiroh, 2007: 103).

Dengan menggunakan pendekatan ekonomi, zakat dapat berkembang menjadi konsep muamalat atau kemasyarakatan, yakni konsep tata cara manusia dalam kehidupan bermasyarakat, termasuk dalam bentuk ekonomi. Apabila kita telusuri turunnya kewajiban zakat, akan dijumpai alasan-alasan yang kuat untuk menghubungkannya dengan konsep kemasyarakatan, bahkan juga kenegaraan. Surah at-Taubah ayat 60 
secara rinci membeberkan perihal zakat.

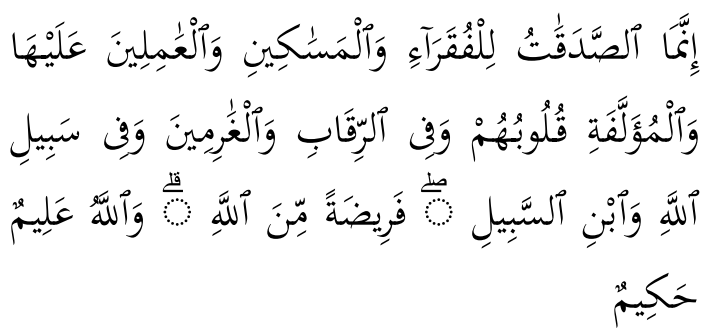

Sesungguhnya sedekah-sedekah (zakat) itu hanyalah untuk orangorang fakir, dan orang-orang miskin, dan amil-amil yang mengurusnya, dan orang-orang muallaf yang dijinakkan hatinya, dan untuk hamba-hamba yang hendak memerdekakan dirinya, dan orangorang yang berhutang, dan untuk (dibelanjakan pada) jalan Allah, dan orang-orang musafir (yang keputusan) dalam perjalanan. (Ketetapan hukum yang demikian itu ialah) sebagai satu ketetapan (yang datangnya) dari Allah. Dan (ingatlah) Allah Maha Mengetahui, lagi Maha Bijaksana. (Q.S. atTaubah [9]: 60)

Agaknya perlu senantiasa ditingkatkan penerapan zakat secara produktif. Pengembangan zakat bersifat produktif dengan cara dijadikannya dana zakat sebagai modal usaha, untuk pemberdayaan ekonomi penerimanya, dan supaya fakir miskin dapat menjalankan atau membiayai kehidupannya secara konsisten. Dengan dana zakat tersebut fakir miskin akan mendapatkan penghasilan tetap, meningkatkan usaha, mengembangkan usaha serta mereka dapat menyisihkan penghasilannya untuk menabung.

\section{Zakat sebagai Alat untuk Memerangi Masalah Riba.}

Dalam ilmu ekonomi Islam juga menaruh perhatian serius terhadap persoalan riba. Riba saat ini telah mengakar sehingga perlu alat untuk menaklukkan sistem ribawi. Zakat mempunyai peran penting untuk perang melawan riba tersebut.

Suatu sistem ekonomi Islam harus bebas dari bunga (riba), riba merupakan pemerasan kepada orang yang sesak hidupnya (terdesak oleh kebutuhan). Islam sangat mencela penggunaan modal yang mengandung riba. Dengan alasan inilah, modal telah menduduki tempat yang khusus dalam ilmu ekonomi Islam. Negara mempunyai hak untuk turun tangan bila modal digunakan untuk merugikan masyarakat. Tersedia hukuman yang berat bagi mereka yang menyalahgunakan kekayaan untuk merugikan masyarakat.

Siapapun orang yang berkutat dengan riba maka cepat atau lambat, mereka akan mengetahui bahwa riba itu akan menggerogoti sistem perekonomian, mungkin di salah satu sisi menyebabkan riba tersebut menguntungkan namun disisi lain dan pada saat yang sama riba menyebabkan kehancuran dan penindasan, karena itulah Allah dan rasulNya melaknat pihak-pihak yang terlibat dalam proses pelaksanaan riba. Dengan penyediaan modal berarti tertutuplah pintu sistem pinjaman yang dikenakan riba. Modal daripada zakat itu boleh diberikan kepada fakir miskin yang berkeinginan untuk membuka 
sesuatu pekerjaan yang sesuai dengan kemampuannya secara gratis atau pinjaman kebaikan (qardhul hasan).

\section{Zakat sebagai Sistem Nilai dalam Islam}

Pengelolaan zakat dapat diorientasikan pada nilai-nilai Islam yang lebih luas. Konsep lain yang terdapat dalam Alquran adalah mengenai 'aqobah yang dapat diterjemahkan sebagai the great ascend untuk meminjam istilah ekonomi Robert Heibroner atau pendakian yang tinggi. Maksudnya ialah upaya mengandung tantangan berat, seperti memerdekakan budak, memberi makanan di hari kelaparan, memelihara serta menolong anak yatim, menolong fakir miskin yang dalam kelaparan, hal ini dapat dilihat pada surat al-Balad ayat 1216.

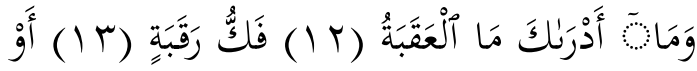

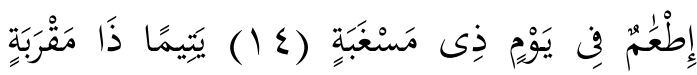

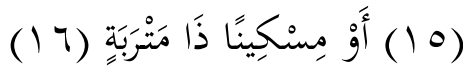

12. Dan apa jalannya engkau dapat mengetahui: apa dia amal-amal yang tinggi darjatnya di sisi Tuhan itu?

13. (Di antara amal-amal itu - bagi orang yang mampu) ialah: memerdekakan hamba abdi.

14. Atau memberi makan pada hari kelaparan.

15. Kepada anak yatim dari kaum kerabat.

16. Atau kepada orang miskin yang terlantar di atas tanah.(Q.S. alBalad [90]: 12-16)
Antara konsep 'aqobah birr dan zakat terdapat titik persamaan. Tindakan zakat perlu dilandasi dengan semangat birr yaitu: kamu tidak akan mendapat nilai kebajikan (birr) sehingga kamu membelanjakan dari apa yang kamu cintai, Firman Allah:

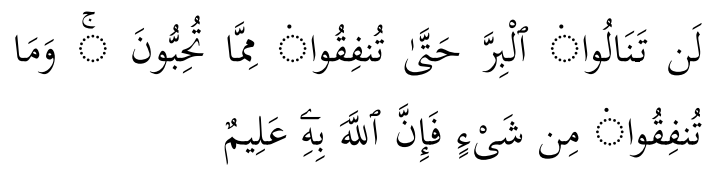

Kamu tidak sekali-kali akan dapat mencapai (hakikat) kebajikan dan kebaktian (yang sempurna) sebelum kamu dermakan sebahagian dari apa yang kamu sayangi. Dan sesuatu apa pun yang kamu dermakan maka sesungguhnya Allah mengetahuinya. (Q.S. Ali Imran [3]: 92)

Demikian pula suatu tindakan individual atau kolektif (termasuk kebijakan ekonomi) untuk merealisasikan aqobah dapat

dilakukan melalui zakat yang dilandasi oleh motivasi birr. Dengan demikian, zakat mengandung makna etis sosial yang luas guna menuju sasaran yang jelas.

Secara horizontal zakat berperan dalam mewujudkan keadilan dan kesetiakawanan sosial dan menunjang terwujudnya keamanan dalam masyarakat dari berbagai perbuatan negatif seperti pencurian atau tindakan kriminal lainnya, karena harta hanya beredar di antara orang-orang kaya saja. Tujuan secara horizontal ini tampak secara jelas, karena di dalam zakat telah ditetapkan ketentuan dan proseduralnya seperti batas nisab, haul, dan kadar zakat yang harus dikeluarkan serta kriteria para 
mustahik. Pada akhirnya akan memupuk amal saleh di tengah masyarakat.

Aspek amal saleh kepada masyarakat mengandung segi sosial dan ekonomi. Segi sosial adalah untuk kemaslahatan pribadi dan kemaslahatan umum. Segi ekonomis adalah harta benda itu harus berputar di tengah masyarakat, menjadi daya dorong untuk perputaran ekonomi dalam masyarakat.

\section{Zakat sebagai Sarana Distribusi Pendapatan}

Sistem ekonomi Islam mengakui adanya perbedaan pendapatan penghasilan dan kekayaan pada setiap orang dengan syarat bahwa perbedaan tersebut diakibatkan karena setiap orang mempunyai perbedaan keterampilan, insiatif, usaha, dan resiko.

Namun perbedaan itu tidak boleh menimbulkan kesenjangan yang terlalu dalam antara yang kaya dengan yang miskin sebab kesenjangan yang terlalu dalam tersebut tidak sesuai dengan syariah Islam yang menekankan sumbersumber daya di samping merupakan karunia Allah juga merupakan suatu amanah. Oleh karena itu, tidak ada alasan untuk mengkonsentrasikan sumber-sumber daya di tangan segelintir orang.

Syariat Islam sangat menekankan adanya suatu distribusi kekayaan dan pendapatan yang merata sebagaimana yang tercantum dalam Al Quran Surah Al Hasyr ayat 7,

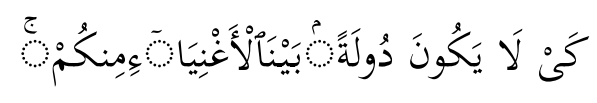

"...supaya harta itu tidak hanya beredar di antara orang-orang kaya dari kalangan kamu..." (Q.S. alHasyr [59]: 7)

Ini berarti bahwa Islam tidak menghendaki adanya kecenderungan konsentrasi kekayaan pada sekelompok elite masyarakat. Oleh karena itu pemerintah mempunyai peranan penting dalam perekonomian, utamanya dalam distribusi pendapatan.

Campur tangan pemerintah dalam perekonomian akan menimbulkan tiga jenis aliran baru dalam sirkulasi aliran pendapatan, yakni: (Sukirno, 2006: 151)

1. Pembayaran pajak oleh rumah tangga dan perusahaan kepada pemerintah. Pembayaran pajak tersebut menimbulkan pendapatan kepada pihak pemerintah, yang mana pajak inilah yang menjadi pendapatan utama pemerintah.

2. Pengeluaran dari sektor pemerintah ke sektor perusahaan. Aliran ini menggambarkan nilai pengeluaran pemerintah terhadap barang-barang dan jasa-jasa yang diproduksi oleh sektor perusahaan.

3. Aliran pendapatan dari sektor pemerintah ke sektor rumah tangga. Aliran ini muncul sebagai akibat dari pembayaran terhadap konsumsi faktor-faktor produksi yang dimiliki sektor rumah tangga oleh pemerintah. 
Salah satu variabel penting yang diperlukan untuk menjamin keadilan dalam pertumbuhan ekonomi sebuah negara adalah adanya keseimbangan distribusi pendapatan dan kekayaan. Menurut ekonom syariah Malaysia, Prof Aslam Haneef, dalam perspektif makroekonomi syariah, konsep distribusi ini dapat ditinjau dari tiga aspek. Analisa terhadap ketiga aspek distribusi ini dapat dijadikan sebagai landasan untuk menjustifikasi apakah pembangunan ekonomi sebuah negara akan melahirkan pemerataan dan keadilan, atau sebaliknya, justru akan melahirkan kesenjangan yang semakin melebar antara kelompok kaya dengan kelompok miskin (BAZNAS, http://pusat.baznas.go.id/, diakses pada 1 September 2015).

Pertama adalah pre-production distribution, yaitu distribusi praproduksi. Dalam hal ini, indikator makro yang digunakan adalah Anggaran Pendapatan dan Belanja Negara (APBN). Jika sebuah negara memiliki struktur APBN yang propoor, dimana alokasi anggaran untuk pemberdayaan kelompok miskin sangat signifikan, maka arah kebijakan pembangunan negara tersebut dipastikan berada pada jalur yang benar. Sebaliknya, struktur APBN yang tidak berpihak pada kelompok duafa merupakan sinyal kuat akan munculnya pertumbuhan ekonomi yang tidak berkeadilan, apalagi untuk negara yang sangat mengandalkan pengeluaran pemerintah dalam menstimulasi economic growth.
Kedua, post-production

distribution, yaitu distribusi pascaproduksi, dimana ia terkait dengan reward yang diterima oleh masing-masing faktor produksi, seperti tenaga kerja dan modal, berdasarkan keterlibatan mereka dalam proses produksi, baik melalui mekanisme pasar maupun melalui intervensi pemerintah. Salah satu contoh indikator makro yang dapat digunakan adalah kebijakan upah minimum regional (UMR), yang memberi dampak langsung terhadap kesejahteraan kelompok buruh. Kebijakan UMR yang didasarkan atas pertimbangan keadilan dan kemaslahatan publik akan menciptakan pemerataan dalam pembangunan ekonomi nasional.

$$
\text { Sementara yang ketiga }
$$
adalah redistribution (redistribusi ekonomi), yang terdiri dari tiga instrumen, yaitu: instrumen positif (zakat), instrumen sukarela (infak/sedekah dan wakaf), dan instrumen terlarang (larangan riba/bunga dan penimbunan/spekulasi).

Dua instrumen pertama akan menjamin terciptanya aliran kekayaan dan pendapatan dari kelompok kaya kepada kelompok miskin, sedangkan instrumen ketiga akan mencegah terkonsentrasikannya kekayaan di tangan segelintir kelompok.

\section{PENUTUP}

\section{Kesimpulan}

Ekonomi Islam menyeimbangkan antara kepentingan individu dan 
masyarakat. Salah satu bentuk instrumen penyeimbang dalam ilmu ekonomi Islam adalah zakat. Peranan zakat sangat besar dalam perspektif ilmu ekonomi Islam. Zakat juga merupakan benteng keamanan dalam sistem ekonomi Islam sebagai jaminan ke arah stabilitas ekonomi dan kesinambungan kesejahteraan masyarakat.

\section{Saran}

Semua kaum muslimin harus menyadari akan urgensi zakat dan manfaatnya bagi umat. Pemerintah pun harus selalu berusaha memperhatikan tata kelola zakat, sehingga zakat dapat mensejahterakan.

\section{DAFTAR KEPUSTAKAAN}

Ahmad, Zainal Abidin. 1979. Dasardasar Ekonomi Islam, Jakarta: Bulan Bintang, cetakan iv.

Al Fauzan, Saleh. 2006. Fiqih Seharihari, Jakarta: Gema Insani.

Al-Zuhayly, Wahbah. 1995. Zakat Kajian Berbagai Mazhab, diterjemahkan oleh Agus Efendi dan Bahruddin Fannany, Bandung : PT Remaja Rosdakarya.

Ambary, Hasan Muarif, dkk. 1999. Ensiklopedi Islam, Jakarta: PT Ichtiar Baru Van Hueve, jilid 5.

Ar Rahman, Syaikh Muhammad Abdul Malik. 2003. 1001 Masalah Dan Solusinya, Jakarta: Pustaka Cerdas Zakat.
BAZNAS, 2015. Zakat dan Distribusi Ekonomi. http: //pusat.baznas.go.id/ diakses pada 1 September 2015).

Fakhruddin, 2008. Fiqih dan Manajemen Zakat di Indonesia, Malang: UIN-Malang Press.

Karim, Adiwarman A. 2001. Ekonomi Islam Suatu Kajian Kontemporer, Jakarta: Gema Insani.

-------, Adiwarman A. 2007. Ekonomi Makro Islami, Jakarta: PT Rajagrafindo Persada.

Khasanah, Umrotul. 2010. Manajemen Zakat Modern, Malang: UIN Maliki Press, Cet. I

Maghfiroh, Mamluatul. 2007. Zakat. Yogyakarta: PT Pustaka Insan Madani.

Mahmud, Abdul Hamid. 2006. Ekonomi Zakat. Jakarta: RajaGrafindo Persada.

Mannan, Muhammad Abdul. 1980. Islamic Economics, Theory and Practice, India: Idarah Adabiyah.

Mas'ud, Ridwan dan Muhammad, 2005. Zakat dan Kemiskinan: Instrumen Pemberdayaan Ekonomi Umat, Yogyakarta, UII Press.

Naqvi, Syed Nawab Haider. 2009. Menggagas Ilmu Ekonomi Islam, terj. M. Saiful Anam dan Muhammad Ufuqul Mubin, Yogyakarta: Pustaka Pelajar.

Nasution, Mustafa Edwin, dkk. 2006. Pengenalan Eksklusif Ekonomi Islam, Jakarta: kencana. 
Purwakananta, Moh. Arifin dan Aflaf, Noor. 2011. Zakat for Poverty Alleviation, Forum Zakat (FOZ) dan World Zakat Forum (WZF), Jakarta.

Rasyid, Sulaiman. 1994. Fiqih Islam, Bandung: Sinar Baru Algesindo.

Sabiq, Sayyid. 1982. Fiqih Sunnah 3, Bandung: PT Al Maarif.
Sukirno, Sadono. 2006. Makroekonomi Teori Pengantar, Jakarta: PT Rajagrafindo Persada.

Sakti, Ali. 2007. Ekonomi Islam: Jawaban atas Kekacauan Ekonomi Modern. Jakarta: Paradigma dan Aqsa Publishing.

Yuliadi, Imamudin. 2006. Ekonomi Islam, Yogyakarta: LPPI. 